\title{
The Profitability of Fundamental Trading Rules in Emerging Stock Markets: The Case of Kuwait
}

\author{
Sulaiman T. Al-Abduljader (Corresponding Author) \\ Gulf University for Science and Technology (GUST), Kuwait \\ E-mail: sjader@remas.com.kw \\ Hussain Al-Muraikhi \\ Public Authority for Applied Education and Training, Kuwait \\ E-mail: hf.almuraikhi@paaet.edu.kw
}

Received: September 30, $2010 \quad$ Accepted: January 28, $2011 \quad$ doi:10.5539/ijef.v3n2p223

\begin{abstract}
In this paper, evidence is presented on the profitability of a fundamental trading rule as applied to the Kuwait stock market. Data on forty four stock prices and four fundamental variables (earnings per share, price-to-earnings ratio, price-to-book value ratio, and dividend yield) over fifty five weeks is used for this purpose. Two hypothetical strategies are applied, buy and sell and buy and hold. The results reveal that the buy and sell strategy is more profitable than the buy and hold strategy.
\end{abstract}

Keywords: International Financial Markets, Asset Pricing, Investment Decisions, Financial Economics JEL: G11, G12, G15, P43

\section{Introduction}

Many studies have analyzed the predominant investment analysis techniques applied in major stock markets. The main techniques considered are fundamental analysis, technical analysis, portfolio analysis, capital market theory, and institutional orientation. Eitman and Smith (1974) present an impressionistic view of the changing effect of the introduction of investment techniques over time. Recently, many studies have been conducted that focus on two techniques: fundamental analysis and technical analysis. The role of fundamentalists and technicians remains a topic of debate for academics and practitioners. Practitioners, in particular, seek to identify the technique that is more profitable in developed and emerging stock markets.

Theoretically, fundamental analysts observe deviations from an equilibrium level of price as implied by a fundamental model. This deviation will ultimately trigger a buy/sell signal as it signifies an undervalued/overvalued stock. Fundamentalists believe that stock prices will eventually return to their fundamental fair value and, consequently, opportunities arise from taking a position prior to the stock price reaching the equilibrium level (Al-Abduljader, 2008). However, this is not necessarily the case as technical analysts may believe that there is no indication of a trend reversal and, consequently, they will continue to buy an asset while fundamentalists are selling. This study provides an empirical investigation into the profitability of a fundamental trading rule as applied to the stock market of Kuwait. The paper starts with a theoretical description of trading on the basis of fundamental analysis. The study then presents a review of the relevant studies of both developed and emerging markets to assess the profitability of trading based on fundamental analysis. This is followed by model specification and the empirical results and we end up with some concluding remarks.

\section{Literature Review}

Fundamental stock valuation based on discounted cash flows (DCF) is attained by discounting future cash flows (dividends) at a pre-determined discount rate (the required rate of return). Penman (1992) defines fundamental analysis as the evaluation, using accounting concepts, of asset values to attain "the investment worth". The essence of determining the present (fair) value of an asset is simply the sum of the discounted future cash flows and the discounted sale (terminal) price of the asset. The present (fair) value, therefore, is the price an investor is willing to pay for the asset.

For stock valuation, the projected cash flows are represented by earnings and dividends. It is common practice to use the price-to-earnings $(\mathrm{P} / \mathrm{E})$ multiple approach on a company for short-term stock trading. According to this technique, the fair value (price) is obtained by multiplying the expected earnings per share by the industry's average $\mathrm{P} / \mathrm{E}$ ratio. Although discounting future dividends is more accurate, the simple calculation is prevalent among 
investors in emerging markets.

The dividend discount model (DDM) has been developed by Miller and Modigliani (1961) to obtain an equilibrium (fair) price of a stock by discounting expected dividends. The model can be expressed as

$$
\bar{P}=\frac{D_{1}}{(1+i)}+\frac{D_{2}}{(1+i)^{2}}+\frac{D_{3}}{(1+i)^{3}}+\cdots+\frac{D_{\infty}}{(1+i)^{\infty}}=\sum_{t=1}^{\infty} \frac{D_{t}}{(1+i)^{t}}
$$

where $D_{t}$ is the dividend paid at time $t, i$ is the required rate of return and $\bar{P}$ is the fair price. If the stock is held until point in time $s$, then sold at $P_{s}$, then the model can be re-written as

$$
\bar{P}=\sum_{t=1}^{s} \frac{D_{t}}{(1+i)^{t}}+\frac{P_{s}}{(1+i)^{s}}
$$

Since $P_{s}$ depends on dividends paid from ${ }_{\mathrm{s}+1}$ to $\infty$, the model becomes

$$
\bar{P}=\sum_{t=1}^{s} \frac{D_{t}}{(1+i)^{t}}+\sum_{t=s+1}^{\infty} \frac{D_{s+1}}{(1+i)^{t}}
$$

If the stock does not currently pay dividends but will start at time $t=s$, the model then can be written as

$$
\bar{P}=\sum_{t=s}^{\infty} \frac{D_{t}}{(1+i)^{t}}
$$

Assuming that dividends grow at a constant rate, Gordon and Shapiro (1956) and Gordon (1962) applied this assumption to Equation (4) and developed a simple model of the fair value, which is presented as

$$
\bar{P}=\frac{D_{1}}{i-g}
$$

where $g$ is the expected growth rate of dividends.

Fuller and Hsia (1984) extended the DDM and developed a variant of a two-stage model in which the growth rate begins high and then declines over time. The value of the expected dividends can be extracted using what is referred to as the H-model, which is

$$
\bar{P}=\frac{D_{0}\left(1+g_{L}\right)}{i-g_{L}}+\frac{D_{0} H\left(g_{S}-g_{L}\right)}{i-g_{L}}
$$

in which $H$ is the half-life in years of the high-growth period, $g_{L}$ is the normal long-term dividend growth rate after year $2 \mathrm{H}$, and $g_{S}$ is the initial short-term dividend growth rate. The first term on the right-hand side of Equation (6) represents the extra value extracted from the high growth rate in the early years, assuming that the short-term growth rate is higher than the normal long-term growth rate. The second term is simply an expression for the present value of the firm, assuming that it grows at its normal long-term growth rate.

In summary, the model, in its various versions and extensions, mainly postulates the identification of the present value of future cash flows. Since determining the expected future dividends depends on the analyst's view of the stock's future performance and the company's stock dividend policy, several approaches are suggested to capture a more precise valuation of a stock. As an alternative to discounting expected dividends, firm valuation can be obtained by discounting the expected free cash flow to the firm (FCFF).

The free cash flow to the firm is the capital available after all operating expenses and investments have been covered. FCFF can calculated as follows

$$
F C F F=N I+N C C+\operatorname{Int}(1-T a x)-F C-W C
$$

where $N I$ is net income to common shareholders, $N C C$ is net non-cash charges, Int is interest expense, $F C$ is investment in fixed capital and $W C$ is investment in working capital. By assuming a constant growth rate, the firm value then can be calculated as

$$
\bar{P}=\frac{F C F F_{0}(1+g)}{W A C C-g}
$$

where $W A C C$ is the weighted average cost of capital for the firm. 
The multiples approach is used more for dynamic trading. Price multiples are ratios of a stock market price relative to some measure of its value. Price multiples are used to find out if a stock price is higher/lower than its intrinsic value, which helps traders judge if the stock is over/under valued. The method mostly used is that of comparables, which involves comparing the stock price multiples with a benchmark.

Graham and Dodd (1934) were the first to describe the common stock valuation based on P/Es. One method of determining earnings is based on the historical average EPS, which is used to forecast the growth of EPS for a firm. Other methods have been developed. For instance, Whitbeck and Kisor (1963) and Malkiel and Cragg (1970) proposed a model for calculating predicted $\mathrm{P} / \mathrm{Es}$ based on cross-sectional regressions of $\mathrm{P} / \mathrm{Es}$. Alternatives to the price to earnings ratio are the price to book value $(\mathrm{P} / \mathrm{B})$ ratio, price to sales $(\mathrm{P} / \mathrm{S})$ ratio and price to cash flow $(\mathrm{P} / \mathrm{CF})$ ratio.

Various studies have investigated the relation between stock prices and fundamental company variables, such as dividend payouts, capital structure, earnings growth, merger announcements and dividend yields. For example, Benesh et al. (1984) investigated the effects of dividend policy on stockholders and found that investors react positively to hefty payouts and vice versa. More recently, Gurgul et al. (2006) examined the German stock market and reached a similar conclusion of positive correlation between stock prices and dividend payouts. Gunasekarage and Power (2006) reached a similar conclusion when investigating U.K. listed firms.

Short-term traders (1-3 month investment horizon) typically question the effectiveness of utilising fundamental analysis for the purpose of obtaining buy/sell trading signals. Shiller (1981) puts forward the argument that the substantial volatility of stock prices cannot be justified by solely relying on fundamental valuation. Campbell and Shiller (1988) state that other variables also affect stock price volatility such as noise, feedback trading and irrational expectations. Furthermore, Zhong et al. (2003) advocated the incorporation of time-varying expected inflation in the DDM to capture a more realistic stock behaviour.

Consequently, some have drawn a conclusion that the macroeconomic determinants of stock prices are more informative than those appearing in classic fundamental models, since the former incorporate the general outlook of the economy and the systematic risk effects on stock prices (Darrat et al., 1996, Flannery and Protopapadakis, 2002 and McMillan, 2005). Such conclusions are aligned with the arbitrage pricing theory (APT).

The literature documents the profitability of trading rules based on the deviation from the equilibrium price. Table 1 provides the results of recent studies that investigated the role of fundamentalists in developed and emerging financial markets. For instance, Quirin et al. (2000) focused on studying the effect of fundamental analysis on oil and gas firm valuation. The results revealed a significant relation between fundamental variables and stock returns.

Trading based on financial statement analysis was also confirmed by Nissim and Penman (2001). Aby et al. (2001) focused on major ratios and tested their ability to predict stock returns. The results show a significantly positive relation between market prices and both $(\mathrm{P} / \mathrm{E})$ ratios and book values. Fundamental analysis profitability was examined by Abarbanell and Bushee (1997), which indicated a strong link between accounting information and earnings changes. Further, Chan et al. (1993) confirm the predictability of Japanese stock returns using various fundamental methods. The findings show that the book-to-market ratio and cash flow yield are the two most significant fundamental variables in relation to Japanese expected returns. Several studies focused on fundamental valuation and stock short selling. For instance, Dechow et al. (2001) looked at the fundamental ratios and short-sell positions of certain stocks. The study revealed a relation between low ratios to market value and lower future stock returns.

The literature also documents the evidence on the effectiveness of fundamental analysis in emerging stock markets. Mukherji et al. (1997) examined the Korean stock market for the period between 1982 and 1993, providing results revealing that stock returns were positively related to book-market, sales-price and debt-equity ratios, and negatively related to firm size. Moreover, Dhankani (2005) examined the Indian stock market and tested correlation between accounting information and stock returns. Over a sample period of five years (2000-2005), the results show strong correlation between a firm's short-term operating efficiency, profitability figures and contemporaneous stock prices.

Al-Muraikhi (2005) examined the profitability of models based on explanatory variables and those based on the HP filter. The study used six financial time series, one stock market index and one stock listed on the Kuwait Stock Exchange. The results suggest that the trading rules seemed to work better in the stock market than in the foreign exchange market. Within the stock market, the trading rules worked better for individual stocks than for the market index.

More recently, Al-Abduljader (2008) investigated the roles of both fundamentalists and technicians with eight companies listed on the Kuwait Stock Exchange. The study utilised daily data spanning over eight years. The results indicate that fundamentalists and technicians, more or less, are of similar importance in stock price determination. 


\section{Model Specification and Empirical Results}

To estimate the equilibrium stock price, the following explanatory variables are used: earnings per share (EP), price-to-earnings ratio (PE), price-to-book value ratio (PB) and dividend yield (DY). The model is specified as follows:

$$
P_{t}=a_{t}+\beta_{1} E P_{t}+\beta_{2} P E_{t}+\beta_{3} P B_{t}+\beta_{4} D Y_{t}+\xi_{t}
$$

This model is used just for the purpose of calculating the predicted value of $P_{t}$, not for judging the importance of individual explanatory variables. Hence, issues related to the distribution of the estimated standard errors and $t$ statistics are overlooked. Nonetheless, the explanatory variables are stationary. And in any case, if this proves to be a problem, the model can be specified by making the dependant variable the first log difference of $P$.

The data used is weekly stock prices of forty four Kuwaiti public companies for the period between 19 July, 2006 and 8 August, 2007. The data was obtained from Global Investment House. Table 2 presents a list of the companies under investigation which belong to a diverse set of sectors.

The results of the estimated model are shown in Table 3. The estimation results include the coefficient of determination in addition to the diagnostics for serial correlation $(S C)$ and heteroscedasticity $(H S)$ as well as the parenthesis which denotes the t-statistic. It is evident that the model has a reasonable goodness of fit and, with a few exceptions, passes the two diagnostics. After obtaining the equilibrium stock price, which is predicted by the model, we then apply two trading rules "buy and sell" and "buy and hold". For the buy and sell strategy, assume that the price is observed at points of time $t, t+1 \ldots . t+n$. The price at time $t, P_{t}$, generates a buy signal if

$$
P_{t}-\bar{P}<0
$$

where $\bar{P}$ is the equilibrium stock price. Similarly, a sell signal is generated if

$$
P_{t}-\bar{P}>0
$$

By employing an $x$ per cent filter, the trading rule is modified as follows. The buy signal emerges at $P_{t}$ if

$$
P_{t}=(1-x) \overline{P_{t}}
$$

On the other hand, a sell signal emerges at $P_{t}$ if

$$
P_{t}=(1+x) \bar{P}
$$

For this study, we set $x=0.01$. To calculate the cumulative profit generated by the two strategies, we define $K$ to the initial capital invested. The profit generated on the buy and sell strategy $R_{t+1}$ is calculated as

$$
R_{t+1}=K_{t+1}\left(\frac{P_{t+1}}{P_{t}}-1\right)
$$

where the $P_{t}$ is the buy price and the $P_{t+1}$ is the sell price. Similarly, the cumulative profit made from the buy and hold strategy, $R_{n}$ is defined as

$$
R_{n}=K\left(\frac{P_{n}}{P_{t}}-1\right)
$$

where $P_{n}$ is the last sell price in the sample. The calculations are based on the assumption that $K=100$.

Figure 1 shows the percentage deviation from $\bar{P}$ whereas Figure 2 shows the growth of the invested capital resulting from the buy/sell rule. Table 4 presents the net profit (loss) generated by using a rule based on a fundamental model with explanatory variables compared with the buy and hold strategy. The results show that trading based on fundamental analysis is superior to the buy and hold strategy. Thirty three out of forty four stocks generated higher profits when traded based on a fundamental model with explanatory variables.

\section{Conclusion}

This study provides evidence on the profitability of a fundamental trading rule in an emerging stock market. The results revealed that the trading rule is generally profitable as compared with a buy and hold strategy. The paper, 
however would be further enriched if long-term data was made available. We hope that this paper to stimulate further testing in the emerging market under investigation to obtain more robust results on the profitability of the fundamental trading rule over the buy and hold strategy.

\section{Acknowledgement}

The authors would like to acknowledge the comments of the anonymous referees and thank them for their insights.

\section{References}

Abarbanell, J. and Bushee, B. (1997). Fundamental Analysis, Future Earnings, and Stock Prices, Journal of Accounting Research, 35, 1-25.

Aby, C. Briscoe, N., Jones, M. and Kromis, S. (2001). Selection of Undervalued Stock Investments for Pension Plans and Deferred Compensation Programs, Journal of Deferred Compensation, 6, 64-77.

Al-Abduljader, S. (2008). An Empirical Investigation into the Workings of an Emerging Stock Market: The Case of Kuwait, PhD Thesis, La Trobe University.

Al-Muraikhi, H. (2005). Speculation in Emerging Financial Markets: The Case of Kuwait Stock and Foreign Exchange Markets, PhD Thesis, La Trobe University.

Arnold, J. and Moizer, P. (1984). A Survey of the Methods Used by UK Investment Analysts to Appraise Investment in Ordinary Shares, Accounting and Business Research, 14, 195-208.

Benesh, G., Keown, A. and Pinkerton, J. (1984). An Examination of Market Reaction to Substantial Shifts in Dividend Policy, Journal of Financial Research, 7, 131-143.

Campbell, J. and Shiller, R. (1988). The Dividend-Price Ratio and Expectations of Future Dividends and Discount Factors, Review of Financial Studies, 1, 195-228.

Chan, L, Hamao, Y. and Lakonishok, J. (1993). Can Fundamentals Predict Japanese Stock Returns?, Financial Analysts Journal, 49, 63-70.

Courteau, L., Kao, J., O'Keefe, T. and Richardson, G. (2006). Relative Accuracy and Predictive Ability of Direct Valuation Methods, Price to Aggregate Earnings Method and a Hybrid Approach, Accounting and Finance, 46, 553-571.

Darrat, A., Gilley, O. and Meyer, D. (1996). U.S. Oil Consumption, Oil Prices and the Macroeconomy, Empirical Economics, 21, 317-34.

Dechow, P., Huttom, A., Meulbroek, L. and Sloan, R. (2001). Short-Sellers, Fundamental Analysis, and Stock Returns, Journal of Financial Economics, 61, 77-86.

Dhankani, D. (2005). Fundamental Analysis and Stock Returns: India. (2000-2005),The Business Review, Cambridge, 4, 218-23.

Eitman, D. and Smith, K. (1974) A Portfolio Analysis of the Teaching of Investments, Journal of Quantitative Analysis, 9, 771-80.

Fama, E. (1995). Random Walks in Stock Market Prices, Financial Analysts Journal, 51, 75-61.

Flannery, M. and Protopapadakis, A. (2002). Macroeconomic Factors Do Influence Aggregate Stock Returns, The Review of Financial Studies, 15, 751-63.

Fuller, R. and Hsia, C. (1984). A Simplified Common Stock Valuation Model, Financial Analysts Journal, 40, 49-56.

Gordon, M. (1962). The Investment, Financing, and Valuation of the Corporation, Third Edition, RD Irwin. Homewood, Illinois.

Gordon, M. and Shapiro, E. (1956). Capital Equipment Analysis: The Required Rate of Profit, Management Science, 3, 102-110.

Graham, B. and Dodd, D. (1934). Security Analysis, McGraw-Hill Companies, New York.

Guest, O. (2004). The Time Series Properties of the SPI Futures Market and Implications for Financial Decisions, Unpublished PhD Thesis, La Trobe University.

Gunasekarage, A. and Power, D. (2006). Anomalous Evidence in Dividend Announcements Effect, Managerial Finance, 32, 209-227.

Gurgul, H., Majdosz, P. and Mestel, R. (2006). Implications of Dividend Announcements for Stock Prices and 
Trading Volume of DAX Companies, Finance a Uver, 56, 58-71.

Lui, Y. and Mole, D. (1998). The Use of Fundamental and Technical Analyses by Foreign Exchange Dealers: Hong Kong Evidence, Journal of International Money and Finance, 17, 535-548.

Maditinos, D., Sevic, Z. and Theriou, N. (2007). Investors' Behavior in the Athens Stock Exchange (ASE), Studies in Economics and Finance, 24, 32-46.

Malkiel, B. and Cragg, J. (1970). Expectations and the Structure of Share Prices, American Economic Review, 60, 601-617.

McMillan, D. (2005). Time Variation in the Cointegrating Relationship between Stock Prices and Economic Activity, International Review of Applied Economics, 19, 359-78.

Miller, M. and Modigliani F. (1961). Dividend Policy, Growth, and the Valuation of Shares, Journal of Business, 34, 411-433.

Mukherji, S., Dhatt, M. and Kim, Y. (1997). A Fundamental Analysis of Korean Stock Returns, Financial Analysts Journal, 53, 75-81.

Nissim, D. and Penman, S. (2001). Ratio Analysis and Equity Valuation: From Research to Practice, Review of Accounting Studies, 6, 109-123.

Olbert, L. (1994). Stock Valuation Methods of Financial Analysts in a Thin Stock Market in Sweden, with Comparisons to the United Kingdom and the United States, The International Journal of Accounting, 29, 123-39.

Penman, S. (1992). Return to Fundamentals, Journal of Accounting, Auditing \& Finance, 7,465-78.

Quirin, J., Berry, K. and O'Brien, D. (2000). A Fundamental Analysis Approach to Oil and Gas Firm Valuation, Journal of Business Finance and Accounting, 27, 785-96.

Shiller, R. (1981). Do Stock Prices Move Too Much to be Justified by Subsequent Changes in Dividends?, American Economic Review, 71, 421-36.

Whitbeck, V. and Kisor, M. (1963). A New Investment Tool in Investment Decision Making, Financial Analysts Journal, 19, 55-62.

Wong, M. and Cheung, Y. (1999). The Practice of Investment Management in Hong Kong: Market Forecasting and Stock Selection, Omega, 27, 451.

Zhong, M., Darrat, A. and Anderson, D. (2003). Do US Stock Prices Deviate From Their Fundamental Values? Some New Evidence, Journal of Banking and Finance, 27, 673-697.

Table 1. Selected Studies of the Profitability of Fundamental Trading

\begin{tabular}{|l|l|l|}
\hline Author(s) & Data & Results \\
\hline \multirow{3}{*}{ Arnold and Moizer (1984) } & UK stocks & \\
\hline Olbert (1994) & S05 questionnaires & Profitable \\
\hline Fama (1995) & Swedish financial market-survey & Profitable \\
& $\begin{array}{l}\text { U.S stocks } \\
\text { Testing random walk model }\end{array}$ & Profitable \\
\hline Lui and Mole (1998) & FX dealers -Questionnaire survey & Not profitable \\
\hline Wong and Cheung (1999) & Hong Kong stocks - questionnaire & Profitable only for long-term \\
\hline Guest (2004) & Australian spot and futures stocks & Profitable \\
\hline Al-Muraikhi (2005) & Kuwait stocks & Profitable \\
\hline Courteau et al. (2006) & U.S stocks & Profitable \\
\hline Maditinos et al. (2007) & 435 firms (1990-2000) & \\
\hline
\end{tabular}


Table 2. Selected List of Companies

\begin{tabular}{|l|l|}
\hline Stock & Company \\
\hline NBK & National Bank of Kuwait \\
\hline GBK & The Gulf Bank \\
\hline CBK & Commercial Bank of Kuwait \\
\hline ABK & Al-Ahli Bank of Kuwait \\
\hline BURE & Bank of Kuwait and the Middle East \\
\hline KFIN & Burgan Bank \\
\hline KINV & Kuwait Finance House \\
\hline FACI & Kuwait Investment Co. \\
\hline NINV & Commercial Facilities Co. \\
\hline KPRO & National Investment Company \\
\hline SECH & Kuwait Investment Projects Co. (Holding) \\
\hline IICK & The Securities House Co. \\
\hline KMEF & Industrial \& Financial Investments Co. \\
\hline IIGK & Kuwait \& Middle East Financial Investment Co. \\
\hline AIGK & International Investment Group \\
\hline TIDK & Aref Investment Group Co. \\
\hline GIHK & The Investment Dar \\
\hline AAYA & Gulf Investment House \\
\hline GLOB & A'ayan Leasing \& Investment Co. \\
\hline GINS & Global Investment House \\
\hline
\end{tabular}

Table 3. Model Estimation Results

\begin{tabular}{|c|c|c|c|c|c|c|c|}
\hline Stock & $\beta_{1}$ & $\beta_{2}$ & $\beta_{3}$ & $\beta_{4}$ & $R^{2}$ & $S C$ & $H S$ \\
\hline NBK & $\begin{array}{l}0.023 \\
(6.49)\end{array}$ & $\begin{array}{l}0.140 \\
(7.02)\end{array}$ & $\begin{array}{l}0.096 \\
(2.57)\end{array}$ & $\begin{array}{l}0.579 \\
(3.56)\end{array}$ & 0.60 & 0.0005 & 0.040 \\
\hline GBK & $\begin{array}{l}0.009 \\
(1.07) \\
\end{array}$ & $\begin{array}{l}0.034 \\
(0.56)\end{array}$ & $\begin{array}{l}0.127 \\
(2.12)\end{array}$ & $\begin{array}{c}-0.084 \\
(-0.40)\end{array}$ & 0.87 & 0.44 & 0.246 \\
\hline CBK & $\begin{array}{l}0.016 \\
(3.89) \\
\end{array}$ & $\begin{array}{l}0.100 \\
(4.38) \\
\end{array}$ & $\begin{array}{l}-0.027 \\
(-1.17) \\
\end{array}$ & $\begin{array}{l}0.085 \\
(1.24) \\
\end{array}$ & 0.70 & 0.38 & 0.000006 \\
\hline $\mathrm{ABK}$ & $\begin{array}{l}0.013 \\
(7.62)\end{array}$ & $\begin{array}{l}0.063 \\
(6.69)\end{array}$ & $\begin{array}{l}-0.002 \\
(-0.08)\end{array}$ & $\begin{array}{l}0.013 \\
(0.78)\end{array}$ & 0.94 & 0.54 & 0.037 \\
\hline BKME & $\begin{array}{l}0.015 \\
(3.90)\end{array}$ & $\begin{array}{l}0.052 \\
(3.98)\end{array}$ & $\begin{array}{l}-0.044 \\
(-0.85)\end{array}$ & $\begin{array}{l}0.023 \\
(2.35)\end{array}$ & 0.81 & 2.03 & 1.122 \\
\hline BURG & $\begin{array}{l}0.010 \\
(3.73)\end{array}$ & $\begin{array}{l}0.070 \\
(3.34) \\
\end{array}$ & $\begin{array}{c}-0.034 \\
(-0.57)\end{array}$ & $\begin{array}{l}-0.022 \\
(-1.01)\end{array}$ & 0.98 & 1.28 & 2.982 \\
\hline KFIN & $\begin{array}{l}0.028 \\
(3.40) \\
\end{array}$ & $\begin{array}{l}0.150 \\
(3.77)\end{array}$ & $\begin{array}{l}0.082 \\
(2.58)\end{array}$ & $\begin{array}{l}0.681 \\
(1.51) \\
\end{array}$ & 0.87 & 0.000001 & 0.189 \\
\hline KINV & $\begin{array}{c}-0.0003 \\
(-0.57)\end{array}$ & $\begin{array}{l}-0.002 \\
(-1.38)\end{array}$ & $\begin{array}{c}0.330 \\
(7.41) \\
\end{array}$ & $\begin{array}{l}0.005 \\
(3.87) \\
\end{array}$ & 0.69 & 0.12 & 2.411 \\
\hline FACI & $\begin{array}{l}0.008 \\
(1.73)\end{array}$ & $\begin{array}{c}0.049 \\
(1.82) \\
\end{array}$ & $\begin{array}{c}-0.0008 \\
(-0.18)\end{array}$ & $\begin{array}{l}-0.001 \\
(-0.04)\end{array}$ & 0.85 & 0.99 & 0.230 \\
\hline NINV & $\begin{array}{l}0.0018 \\
(2.32) \\
\end{array}$ & $\begin{array}{l}-0.006 \\
(-1.48) \\
\end{array}$ & $\begin{array}{c}0.015 \\
(-1.48) \\
\end{array}$ & $\begin{array}{c}-0.052 \\
(-6.35) \\
\end{array}$ & 0.71 & 2.14 & 0.270 \\
\hline KPRO & $\begin{array}{c}0.002 \\
(12.45)\end{array}$ & $\begin{array}{l}0.009 \\
(0.92)\end{array}$ & $\begin{array}{l}0.149 \\
(3.36)\end{array}$ & $\begin{array}{c}-0.012 \\
(-1.99) \\
\end{array}$ & 0.96 & 1.47 & 5.633 \\
\hline SECH & $\begin{array}{l}-0.006 \\
(-1.37) \\
\end{array}$ & $\begin{array}{r}-0.029 \\
(-1.48) \\
\end{array}$ & $\begin{array}{l}0.018 \\
(1.14) \\
\end{array}$ & $\begin{array}{r}-0.220 \\
(-3.72) \\
\end{array}$ & 0.78 & 4.25 & 0.582 \\
\hline IICK & $\begin{array}{l}0.003 \\
(2.05) \\
\end{array}$ & $\begin{array}{l}0.004 \\
(2.09) \\
\end{array}$ & $\begin{array}{l}-0.193 \\
(-1.56)\end{array}$ & $\begin{array}{l}-0.089 \\
(-2.94)\end{array}$ & 0.82 & 0.61 & 1.015 \\
\hline KMEF & $\begin{array}{c}0.012 \\
(10.01)\end{array}$ & $\begin{array}{c}0.042 \\
(5.68) \\
\end{array}$ & $\begin{array}{l}-0.070 \\
(-1.51)\end{array}$ & $\begin{array}{c}-0.002 \\
(-0.54)\end{array}$ & 0.79 & 0.98 & 0.039 \\
\hline IIGK & $\begin{array}{l}0.005 \\
(6.29)\end{array}$ & $\begin{array}{l}0.058 \\
(4.14) \\
\end{array}$ & $\begin{array}{l}0.017 \\
(1.70)\end{array}$ & $\begin{array}{c}-0.0002 \\
(-0.02)\end{array}$ & 0.89 & 0.19 & 0.364 \\
\hline AIGK & $\begin{array}{l}0.006 \\
(7.54)\end{array}$ & $\begin{array}{l}0.068 \\
(5.65)\end{array}$ & $\begin{array}{l}-0.003 \\
(-0.17)\end{array}$ & $\begin{array}{l}0.014 \\
(1.47)\end{array}$ & 0.66 & 0.01 & 0.427 \\
\hline TIDK & $\begin{array}{l}0.004 \\
(5.39) \\
\end{array}$ & $\begin{array}{l}0.094 \\
(7.08)\end{array}$ & $\begin{array}{l}0.025 \\
(2.14)\end{array}$ & $\begin{array}{c}-0.031 \\
(-2.10)\end{array}$ & 0.63 & 1.88 & 0.356 \\
\hline GIHK & $\begin{array}{l}0.003 \\
(2.05)\end{array}$ & $\begin{array}{l}0.006 \\
(0.74)\end{array}$ & $\begin{array}{l}0.094 \\
(3.98) \\
\end{array}$ & $\begin{array}{c}-0.0006 \\
(-0.77)\end{array}$ & 0.98 & 8.25 & 0.383 \\
\hline AAYA & $\begin{array}{l}0.002 \\
(0.98)\end{array}$ & $\begin{array}{l}0.005 \\
(0.57)\end{array}$ & $\begin{array}{l}0.057 \\
(2.69) \\
\end{array}$ & $\begin{array}{l}-0.010 \\
(-1.43)\end{array}$ & 0.60 & 2.56 & 0.098 \\
\hline
\end{tabular}




\begin{tabular}{|c|c|c|c|c|c|c|c|}
\hline GLOB & $\begin{array}{r}0.008 \\
(9.26) \\
\end{array}$ & $\begin{array}{r}0.087 \\
(8.85) \\
\end{array}$ & $\begin{array}{l}0.014 \\
(2.42) \\
\end{array}$ & $\begin{array}{l}0.004 \\
(0.60) \\
\end{array}$ & 0.88 & 0.47 & 0.0007 \\
\hline GINS & $\begin{array}{r}0.0005 \\
(2.63) \\
\end{array}$ & $\begin{array}{c}0.0004 \\
(0.18) \\
\end{array}$ & $\begin{array}{l}0.006 \\
(5.39) \\
\end{array}$ & $\begin{array}{c}-0.079 \\
(-13.57) \\
\end{array}$ & 0.93 & 0.13 & 0.070 \\
\hline AINS & $\begin{array}{l}0.006 \\
(3.10) \\
\end{array}$ & $\begin{array}{l}0.094 \\
(2.47) \\
\end{array}$ & $\begin{array}{l}-0.109 \\
(-1.41) \\
\end{array}$ & $\begin{array}{l}0.002 \\
(0.06) \\
\end{array}$ & 0.91 & 0.80 & 0.941 \\
\hline WINS & $\begin{array}{l}-0.001 \\
(-1.73) \\
\end{array}$ & $\begin{array}{l}-0.009 \\
(-1.94)\end{array}$ & $\begin{array}{c}0.295 \\
(10.34)\end{array}$ & $\begin{array}{l}-0.007 \\
(-2.82)\end{array}$ & 0.94 & 0.13 & 4.195 \\
\hline FTIK & $\begin{array}{l}0.002 \\
(2.28)\end{array}$ & $\begin{array}{c}0.0003 \\
(1.61)\end{array}$ & $\begin{array}{c}-0.017 \\
(-1.227)\end{array}$ & $\begin{array}{c}-0.078 \\
(-6.996)\end{array}$ & 0.82 & 0.08 & 0.075 \\
\hline NREK & $\begin{array}{l}0.004 \\
(1.71) \\
\end{array}$ & $\begin{array}{l}0.038 \\
(3.53) \\
\end{array}$ & $\begin{array}{l}0.043 \\
(0.85) \\
\end{array}$ & $\begin{array}{l}-0.034 \\
(-1.81) \\
\end{array}$ & 0.69 & 0.70 & 0.060 \\
\hline SREK & $\begin{array}{l}-0.001 \\
(-2.48)\end{array}$ & $\begin{array}{l}-0.001 \\
(-1.83)\end{array}$ & $\begin{array}{l}-0.019 \\
(-0.56)\end{array}$ & $\begin{array}{l}-0.048 \\
(-5.53) \\
\end{array}$ & 0.73 & 0.82 & 0.839 \\
\hline TAMK & $\begin{array}{l}0.010 \\
(1.28) \\
\end{array}$ & $\begin{array}{l}0.007 \\
(1.69) \\
\end{array}$ & $\begin{array}{l}-0.180 \\
(-1.55) \\
\end{array}$ & $\begin{array}{l}-0.162 \\
(-2.93)\end{array}$ & 0.87 & 0.35 & 14.323 \\
\hline AREC & $\begin{array}{l}-0.001 \\
(-0.80) \\
\end{array}$ & $\begin{array}{l}-0.002 \\
(-1.35)\end{array}$ & $\begin{array}{l}0.430 \\
(5.67) \\
\end{array}$ & $\begin{array}{l}0.002 \\
(0.69) \\
\end{array}$ & 0.68 & 0.20 & 0.184 \\
\hline UREC & $\begin{array}{r}0.0005 \\
(1.47) \\
\end{array}$ & $\begin{array}{l}-.0004 \\
(-0.73) \\
\end{array}$ & $\begin{array}{l}0.081 \\
(6.69) \\
\end{array}$ & $\begin{array}{l}-0.012 \\
(-3.04) \\
\end{array}$ & 0.58 & 2.41 & 0.167 \\
\hline INJA & $\begin{array}{l}0.002 \\
(0.89)\end{array}$ & $\begin{array}{l}0.009 \\
(0.85) \\
\end{array}$ & $\begin{array}{l}0.112 \\
(2.38) \\
\end{array}$ & $\begin{array}{l}-0.002 \\
(-0.78)\end{array}$ & 0.78 & 0.07 & 0.665 \\
\hline CRCK & $\begin{array}{l}0.001 \\
(2.69) \\
\end{array}$ & $\begin{array}{l}0.005 \\
(2.32) \\
\end{array}$ & $\begin{array}{l}0.028 \\
(1.88) \\
\end{array}$ & $\begin{array}{l}-0.024 \\
(-6.03) \\
\end{array}$ & 0.67 & 3.80 & 2.954 \\
\hline AYRE & $\begin{array}{l}0.002 \\
(0.85) \\
\end{array}$ & $\begin{array}{l}0.002 \\
(0.48) \\
\end{array}$ & $\begin{array}{l}0.003 \\
(0.19) \\
\end{array}$ & $\begin{array}{l}-0.055 \\
(-2.87)\end{array}$ & 0.89 & 0.41 & 1.152 \\
\hline REFR & $\begin{array}{c}0.0009 \\
(2.92)\end{array}$ & $\begin{array}{c}-0.0003 \\
(-0.71)\end{array}$ & $\begin{array}{c}0.192 \\
(10.51)\end{array}$ & $\begin{array}{l}0.007 \\
(3.83) \\
\end{array}$ & 0.94 & 3.96 & 0.0007 \\
\hline SHOP & $\begin{array}{r}0.003 \\
(7.99) \\
\end{array}$ & $\begin{array}{l}0.004 \\
(8.64) \\
\end{array}$ & $\begin{array}{l}-0.014 \\
(-0.89) \\
\end{array}$ & $\begin{array}{c}-0.0008 \\
(-2.37) \\
\end{array}$ & 0.70 & 2.40 & 0.767 \\
\hline TELE & $\begin{array}{r}0.013 \\
(5.07) \\
\end{array}$ & $\begin{array}{l}0.084 \\
(1.35) \\
\end{array}$ & $\begin{array}{l}0.244 \\
(1.26) \\
\end{array}$ & $\begin{array}{l}0.041 \\
(0.45) \\
\end{array}$ & 0.82 & 0.32 & 3.916 \\
\hline IPGK & $\begin{array}{l}0.005 \\
(5.73)\end{array}$ & $\begin{array}{l}0.030 \\
(6.68) \\
\end{array}$ & $\begin{array}{l}0.051 \\
(1.29) \\
\end{array}$ & $\begin{array}{l}0.004 \\
(1.56) \\
\end{array}$ & 0.84 & 1.38 & 1.513 \\
\hline NMTC & $\begin{array}{l}0.012 \\
(5.49)\end{array}$ & $\begin{array}{l}0.097 \\
(4.67)\end{array}$ & $\begin{array}{l}0.159 \\
(3.28)\end{array}$ & $\begin{array}{l}0.033 \\
(0.96)\end{array}$ & 0.89 & 0.13 & 1.039 \\
\hline SAFW & $\begin{array}{l}0.006 \\
(2.14) \\
\end{array}$ & $\begin{array}{l}0.006 \\
(1.03) \\
\end{array}$ & $\begin{array}{l}0.072 \\
(3.71) \\
\end{array}$ & $\begin{array}{l}0.003 \\
(0.64) \\
\end{array}$ & 0.69 & 0.51 & 2.123 \\
\hline GFCI & $\begin{array}{l}-0.003 \\
(-0.76) \\
\end{array}$ & $\begin{array}{l}-0.018 \\
(-0.79) \\
\end{array}$ & $\begin{array}{l}0.056 \\
(2.63) \\
\end{array}$ & $\begin{array}{l}-0.079 \\
(-2.26) \\
\end{array}$ & 0.93 & 0.07 & 0.588 \\
\hline FCEM & $\begin{array}{l}0.005 \\
(2.29) \\
\end{array}$ & $\begin{array}{l}0.039 \\
(1.81) \\
\end{array}$ & $\begin{array}{c}0.0008 \\
(0.01)\end{array}$ & $\begin{array}{l}0.003 \\
(0.61) \\
\end{array}$ & 0.81 & 0.22 & 1.625 \\
\hline ARIG & $\begin{array}{l}0.003 \\
(5.29) \\
\end{array}$ & $\begin{array}{l}0.009 \\
(3.81) \\
\end{array}$ & $\begin{array}{c}0.0003 \\
(0.39) \\
\end{array}$ & $\begin{array}{l}-0.001 \\
(-1.60) \\
\end{array}$ & 0.59 & 5.38 & 0.241 \\
\hline UGBK & $\begin{array}{l}0.002 \\
(5.10)\end{array}$ & $\begin{array}{l}0.036 \\
(4.53)\end{array}$ & $\begin{array}{l}0.009 \\
(0.27)\end{array}$ & $\begin{array}{l}-0.001 \\
(-0.28)\end{array}$ & 0.95 & 0.05 & 0.771 \\
\hline EKHK & $\begin{array}{l}0.020 \\
(6.47) \\
\end{array}$ & $\begin{array}{l}0.015 \\
(5.04) \\
\end{array}$ & $\begin{array}{l}0.014 \\
(0.84) \\
\end{array}$ & $\begin{array}{l}0.005 \\
(0.61) \\
\end{array}$ & 0.81 & 0.0005 & 0.896 \\
\hline CIBK & $\begin{array}{l}0.003 \\
(2.17) \\
\end{array}$ & $\begin{array}{l}0.092 \\
(1.91) \\
\end{array}$ & $\begin{array}{l}0.104 \\
(1.32) \\
\end{array}$ & $\begin{array}{l}-0.349 \\
(-7.19) \\
\end{array}$ & 0.881 & 9.41 & 8.044 \\
\hline
\end{tabular}


Table 4. Net Profit (Loss)

\begin{tabular}{|c|c|c|}
\hline Stock & Buy and Sell & Buy and Hold \\
\hline NBK & 34.029 & 14 \\
\hline GBK & 37.353 & 38.235 \\
\hline CBK & 59.165 & 21.053 \\
\hline $\mathrm{ABK}$ & 35.468 & 36.986 \\
\hline BKME & 89.775 & 37.705 \\
\hline BURG & 20.351 & 76.667 \\
\hline KFIN & 32.46 & 49.495 \\
\hline KINV & 26.872 & 1.010 \\
\hline FACI & 6.486 & $(11.29)$ \\
\hline NINV & 22.979 & $(2.381)$ \\
\hline KPRO & 65.482 & 114.458 \\
\hline SECH & 22.664 & $(7.792)$ \\
\hline IICK & 9.338 & $(4.630)$ \\
\hline KMEF & 27.333 & $(7.576)$ \\
\hline IIGK & $(13.810)$ & $(22.222)$ \\
\hline AIGK & 23.148 & 0 \\
\hline TIDK & 12.307 & 7.407 \\
\hline GIHK & $(2.685)$ & $(40)$ \\
\hline AAYA & 32.127 & 2.128 \\
\hline GLOB & 26.300 & $(7.216)$ \\
\hline GINS & 27.506 & 45.455 \\
\hline AINS & 14.844 & $(12.857)$ \\
\hline WINS & 18.504 & $(7.292)$ \\
\hline FTIK & 14.969 & 13.514 \\
\hline NREK & 32.910 & 20 \\
\hline SREK & 28.096 & $(6.780)$ \\
\hline TAMK & 11.653 & 35.632 \\
\hline AREC & 33.876 & 5.128 \\
\hline UREC & 16.465 & 13.265 \\
\hline INJA & 13.970 & 7.143 \\
\hline CRCK & 12.013 & $(7.937)$ \\
\hline AYRE & 6.593 & $(7.246)$ \\
\hline REFR & $(8.821)$ & $(32.576)$ \\
\hline SHOP & 16.741 & (8) \\
\hline TELE & 44.618 & 50 \\
\hline IPGK & 25.471 & 13.580 \\
\hline NMTC & 46.581 & 43.617 \\
\hline SAFW & 58.958 & 14.706 \\
\hline GFCI & 18.872 & $(13.726)$ \\
\hline FCEM & 8.832 & (12) \\
\hline ARIG & 26.196 & $(12.857)$ \\
\hline UGBK & 17.912 & 85.780 \\
\hline EKHK & 110.670 & 6.897 \\
\hline CIBK & 27.200 & 27.200 \\
\hline
\end{tabular}




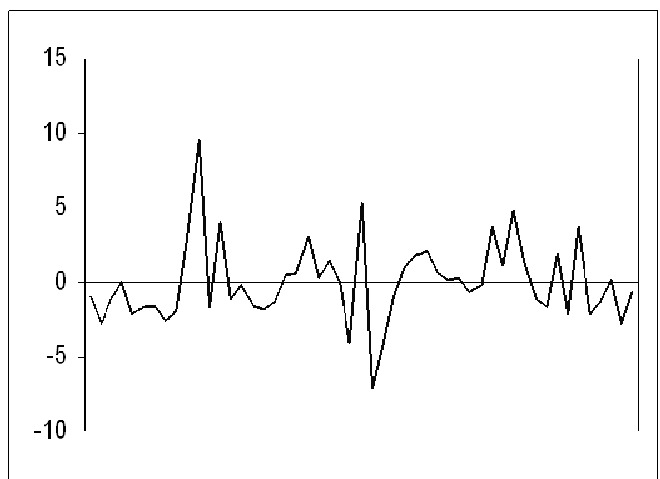

Figure 1(a). Percentage Deviation for NBK

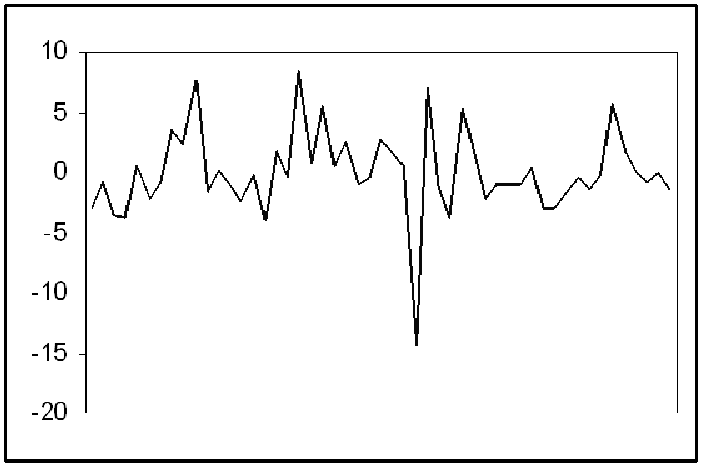

Figure 1(b). Percentage Deviation for GBK

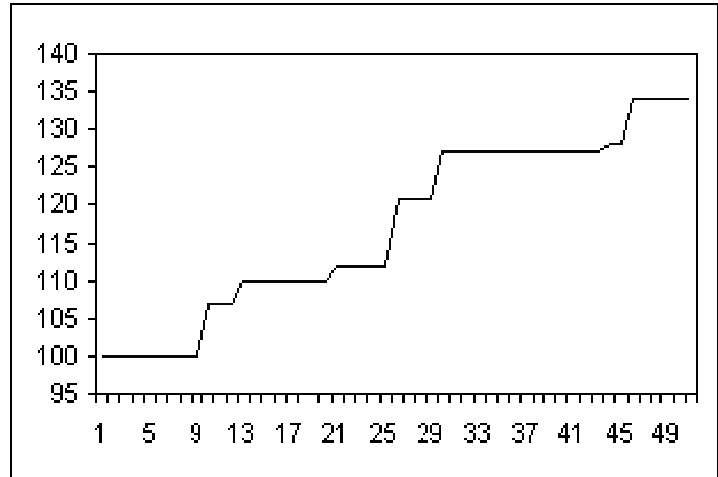

Figure 2(a). The Value of Invested Capital for NBK

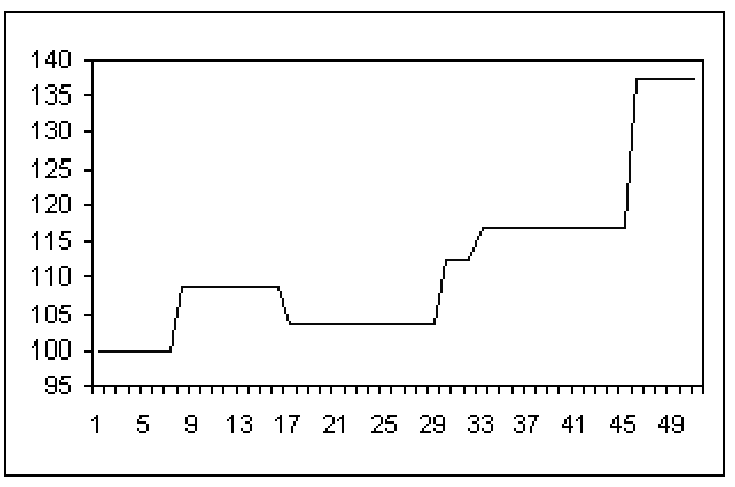

Figure 2(b). The Value of Invested Capital for GBK 